\title{
Tradition, Morality and Solidarity in Durkheim's Theory
}

\author{
Alexander Gofman ${ }^{1}$ (D)
}

\begin{abstract}
This article examines Durkheim's approach to the interrelationship of tradition, morality and solidarity. One of its basic claims is that Durkheim was an epistemological and methodological rationalist, but not an ontological one. It means that he grounded rational and scientific knowledge about social reality, which itself, to his mind, is not rational. It concerns directly his treatment of tradition, morality and social solidarity. In spite of all Durkheim's statements about the decline of traditionalism in contemporary societies, he affirmed sometimes that traditional behaviour in general is almost identical to a moral one. We can see it namely in his reasoning about the close affinity and nearly identical character between "collective habits" and true morality. In industrial societies, according to him, two types of traditions coexist, namely old, "traditional" traditions inherited from the past on the one hand, and new, "rational" traditions, on the other hand. His statements about the alternation of historical periods dominated by traditions and ideals contains a kind of sketch on the philosophy of history, partly explaining the phenomena of time compression and time distension in different periods of social development. Durkheimian theory may be interpreted as a fruitful contribution to the present-day understanding of the processes of modernization.
\end{abstract}

\section{Keywords}

Tradition • Morality • Solidarity • Rules • Emile Durkheim

\footnotetext{
1 Correspondence to: Alexander Gofman (Prof), Social Sciences Department, Higher School of Economics, National Research University, 11 Myasnitskaya Ulitsa, Moscow 101000 Russian Federation. Email: a-gofman@yandex.ru ORCID: 0000-0001-8463-9765
}

To cite this article: Gofman, A. (2019). Tradition, morality and solidarity in Durkheim's theory. İstanbul Üniversitesi Sosyoloji Dergisi, 39, 25-39. https://doi.org/10.26650/SJ.2019.39.1.0007 


\section{Introductory Notes}

It is well known that Durkheim considered morality as a main object of sociological study. He studied this domain for the entirety of his life. In his first fundamental work he tried to demonstrate that the division of labour in society fulfills the moral function, in other words, that it maintains social solidarity. His final, unfinished book, partly published posthumously, was about morality too (Durkheim, 1979a). For many years he delivered University lecture courses about the nature and different fields of this domain, including general morality, contractual morality, professional morals, civic morals, etc. (See for instance: Durkheim, 2012, 2015). Durkheim intended to create a specific science, or sociological discipline which he named either "science of moral facts", or "science of mores" ("science des moeurs"), "physique of mores", or "physique of mores and of law" ("physique des moeurs et du droit"). As a follower of Comte, and unlike Marx, he regarded morality to be a true productive force, a solid basic reality, and an even more "real reality" than the economy or politics.

According to Durkheim, solidarity and regulation, or rules, are two basic sides and at the same time, two distinctive features of morality. ${ }^{2}$ Morality in his theory is inseparable from social solidarity and in a certain sense coincides with it: "... Morality consists in solidarity with the group, and varies according to that solidarity. Cause all social life to vanish, and moral life would vanish at the same time, having no object to cling to.” (Durkheim, 1997, p. 331).

While morality in Durkheimian theory was extensively studied by sociologists for a long time (see, for instance Fish, 2005; Turner, 1993; Wallwork, 1972; Watts Miller, 1996), this cannot be said about his treatment of tradition, which had drawn little attention from analysts. Nevertheless, the problematics of tradition, explicitly and implicitly, occupy an important place in his general theory, as well as in his interpretation of some particular areas of sociological knowledge such as the sociology of morality, of religion, or of law. One of the main objects of the "science des moeurs", according to him, should become the specific traditional norms and practices of different societies. The purpose of this article is to analyze Durkheimian view of tradition in close relation to his treatment of morality and solidarity.

\section{Durkheim and Weber on Reason and Tradition: A Comparison}

To better understand Durkheim's approach to traditions it is useful to compare his views with those of Max Weber's. In spite of all the differences between their respective programs of sociology, in their own studies and reflections that realized these programmes, they had much more in common than it might have

2 On Durkheimian theory of social solidarity and social rules see (Gofman, 2014). 
seemed, to themselves and to many of their interpreters. Besides, these very programmes of both classics at times were the reflections post festum, aimed at explaining, interpreting or justifying the studies that had already been made by them and that had not always exerted much influence on these studies. ${ }^{3}$ Some similarity between their viewpoints is found - especially in their approaches to rationalism, traditions and traditionalism.

Durkheim, as well as Weber, considers the pre-industrial societies to be based on tradition. Just as the German sociologist does, he establishes the fact of the progressive decline of traditionalism and views this decline as a main tendency of social evolution. Both classics note that in contemporary Western societies the detraditionalization is accompanied by the processes of rationalization, intellectualization and, at the same time, by the "disenchantment of the world", as Weber's famous expression had put it. Both think the growing importance of science, technology, industry and corresponding innovations to be the main components of rationalization. Both testify to the crisis of contemporary European societies. Both recognize, if not so much the failure (as the theorists of the Frankfurt school or the "post-modernists" did), but the fundamental complexity and contradictory character of the so called "modernist project" of the Enlightenment.

In Weber's work we can distinguish two concepts of tradition. ${ }^{4}$ One of them denotes a "traditional" action as one of his four famous types of action, along with "affective", "purposeful rational" ("zweck-rational") and "value rational" ("wertrational") actions. In this sense, tradition is identified by him to be a psychological inertia and is interpreted as a kind of action purely imitative, quasi-automatic and habitual. In the second sense Weber interprets tradition as a form of "value rational" action, that is, a social action in which the individual attributes to his behavioural act a subjective sense and orientation toward other individuals.

Doubtless both classics were aware of the crisis of rationalism as a social ideal and analyzed this crisis. Nevertheless, the degrees and the forms of their own rationalism were different. That's why they appreciated the role and the potential of science in the contemporary world in different ways. While, according to Weber, the science cannot intervene in the "eternal struggle of gods", for Durkheim science is just one of these gods (or rather goddess) that take and must take an active part in this struggle. The science which explains and clarifies the values, including sacred values, is itself a sacred value for him. Although both classics are more or less pessimistic in their appraisals of contemporary epoch, nevertheless, unlike Weber who relies only on the "fate", Durkheim believes in science and its ability to contribute to overcoming or reducing the contemporary crisis.

3 On such situation with the Weberian theory of action see, for instance (Joas, 1996, pp. 44-45).

4 In more detail see (Gofman, 2015, pp. 109-124; in Russian). 
In this connection it is important to clarify the specificity of Durkheim's rationalism. No doubt he was a confirmed rationalist and regarded himself to be a sort of Descartes in sociology, whose vocation was to develop "the rules of sociological method", just as Descartes had done two and a half hundred years before him on the "rules of method" in general. He asserts that his "main objective is to extend the scope of scientific rationalism to cover human behaviour by demonstrating that, in the light of the past, it is capable of being reduced to relationships of cause and effect, which, by an operation no less rational, can then be transformed into rules of action for the future." (Durkheim, 1992, p. 33). He sincerely believed in science and its great potential.

Nevertheless, Durkheim by no means belonged to these "big children in university chairs or editorial offices" who believed that science could explain the meaning of the world and of whom Max Weber spoke in his famous lecture "Science as a Vocation." (Weber, 1991, pp. 142-143). In that lecture he also formulated his rhetorical question: "What man will take upon himself the attempt to "refute scientifically" the ethic of the Sermon on the Mount?" (Weber, 1991, p. 148).

Durkheim, despite his fervent rationalism and scientism, would quite willingly accept Weber's rhetorical question because he never set for science such purposes. The aim of science, according to him, is not to refute but to clarify the ethic of the Sermon on the Mount as well as any other ethic. In this respect his point of view completely coincided with Weber's one. He asserted that even the most bizarre and "irrational" cultural and behavioural patterns were to be explained and clarified by science, but not to be refuted at all. He tried to find rational and functional foundation of every institution, custom or ritual. Durkheim wrote in "The Elementary Forms of Religious Life", that "the most bizarre or barbarous rites and the strangest myths translate some human need and some aspect of life, whether social or individual." (Durkheim, 1995, p. 2). And he claimed that "a fundamental postulate of sociology" is "that a human institution cannot rest upon error and falsehood." (Durkheim, 1995 , p. 2). His religious and moral relativism was accompanied by a relativistic and non-universalistic interpretation of rationality. ${ }^{5}$

It can be concluded that in general Durkheim was an epistemological and methodological rationalist, but not an ontological one. It means that he grounded rational and scientific knowledge about social reality which itself, to his mind, is not rational. It is similar to the theory of Freud who meant to construct an ultra-rational science of irrational human reality.

5 He said: "Every moral system has its own rationality."; "All moral systems have their own rationality." (Durkheim, 1979b, pp. 65, 66). 


\section{The Role of Tradition in Durkheim's Theory}

Indeed, social reality in Durkheim's rationalistic interpretation is directed not so much by reason, but by "non-rational component", which consists of religion and morality, based on emotion to a high degree. ${ }^{6}$ Though, according to him, in future societies "...religions will no longer be able to exert very deep or wide sway on consciences" (Durkheim, 1951, p. 375), he did not consider that religion would be replaced by science and believed in the eternity of religion on the whole because it is the primary foundation of social solidarity. He refrained from giving any specific statements concerning the religions of the future. Nevertheless, he expressed his opinion, or rather hopes about their main features. These would be, according to him, their rationalism and individual initiative; and most importantly "the social sense which had always been the soul of religions, will be established in them more straightly and expressly than in the past, not being hidden any more behind the myths and symbols" (La Question religieuse, 1907, p. 51). It means that even in his social ontology Durkheim assigned a certain role to the rational aspect of social life, believing somewhat naively in the direct sense of society without myths and symbols.

The Durkheimian "segmentary" societies with "mechanical" solidarity are based on the similarity or identity of individual consciousnesses which are completely dissolved in "collective" or "common" consciousness. This consciousness, in Durkheim's definition, "the totality of beliefs and sentiments common to the average members of a society..." (Durkheim, 1997, pp. 38-39), is almost synonymous to the notion of traditional consciousness (Durkheim, 1997, p. 39). ${ }^{7}$ In this respect, it has the same high degree of imperativeness and control over consciousness and behaviour of the individuals, as tradition does. Under the influence of the division of labor, the "mechanical" solidarity is replaced with the "organic" one. In societies with the predominance of "organic" solidarity the importance of tradition is less accentuated. They are based on the autonomy of individuals, on the division of functions, on functional interdependence and exchange. At the same time, in this type of societies the "collective" (traditional) consciousness does not disappear, but its prescriptions become vaguer, indefinite and its functioning embraces a much more narrow area of social life.

Although the Durkheimian distinction between two types of societies was largely analytical, he believed, however, that the main tendency of social evolution was the transition of societies with "mechanical" solidarity to more advanced societies with "organic" solidarity. This transition, as it had been noted, is caused by the progressive division of social labor. But, according to Durkheim, this division of labour itself does not create a society. It only transforms a society that already exists. And the preexisting fundamental basis of society consists of a set of traditions realized in collective

6 This thesis was emphasized by Jonathan Fish (Fish, 2005).

7 "...It does not change with every generation but, on the contrary, links successive generations to one another." 
consciousness. In this connection he emphasizes the insufficiency of mere contractual relations for sustaining the social solidarity. This point in Durkheim's theory was once emphasized by Talcott Parsons (Parsons, 1949, pp. 364-365, 461, etc.). Durkheim maintained that the contract presupposed a definite set of shared values and norms which are included into it, and without which its efficient functioning is impossible. He wrote, "But it is not only outside the sphere of contractual relationships, but also on the interplay between these relationships themselves that social action is to be felt. For in a contract not everything is contractual." (Durkheim, 1997, p. 158). In other words, he affirms that even the modern rational social relations cannot exist without sacred value foundation based on tradition to high extent.

Unlike Gabriel Tarde, who considered the decline of traditionalism a transitory phenomenon, ${ }^{8}$ Durkheim claimed the general and steady weakening of the power of tradition in history. Even in cases of traditionalism revival which occur from time to time in different societies, it loses its former strength and efficiency. In order to understand this, it is necessary to compare the different social types at corresponding analogous phases of their development, and not with those which immediately precede these phases. According to Durkheim, "The new societies that replace extinct social types never embark on their course at the very spot where the others came to a halt. How could that be possible? What the child continues is not the old age or the years of maturity of his parents, but their own childhood. Thus if we wish to take stock of the course that has been run we must consider successive societies only at the same stage of their existence." (Durkheim, 1997, p. 121). Applying this principle to appreciating a general role of traditions in social evolution, he wrote, "Doubtless, if we compare the final days of one society with the beginnings of the one that follows it, we perceive a return to traditionalism. Only this phase, by which every social type begins, is always much less violent than it had been in the immediately preceding type. With us ancestral customs have never been the object of superstitious worship such as that devoted to them at Rome. ... In other words the authority of custom is continually diminishing." (Durkheim, 1997, pp. 237-238).

General decline of traditionalism, Durkheim argued, is accompanied by a corresponding decrease of religiosity, its intensity and scale. Indeed, they are the almost identical processes. Among the factors weakening the influence of tradition he emphasized the increase of geographic and social mobility, migrations and urbanization. All these processes undermine the authority of traditions and, at the same time, they intensify the tendency to innovations. They reduce the influence of older generations on younger ones and prompt the progressive autonomy of the latter from the former. Now young people leave their parents' home more often and

8 Tarde treated social evolution as an alternation of traditional epochs based on the custom, and innovative ones based on the "fashion"; in these cases there are two kinds of imitation, namely the ancestors in the former case, and the contemporaries in the latter. 
earlier than before, getting rid of the habitual social environment influence. Old people are real representatives of tradition and living mediators between the past and the present. With the development of civilization the authority and power of the old generations are waning. In contemporary societies the differences between the age groups become less important and the equality between them grows. As Durkheim pointed out, "Old men are pitied rather than feared. Age differences are levelled out. All men, once they have arrived at the age of maturity, treat one another as approximate equals. As a result of this leveling-out, the customs of one's forefathers lose their ascendancy, since for adults they lack anyone to represent them with authority." (Durkheim, 1997, p. 236).

Undoubtedly, in social and political scene of the Third Republic France Durkheim was a convinced anti-traditionalist. But in his general theory traditions play a much more important role than it might seem at first glance. According to him, tradition, as well as the social facts in general, has the coercive and extraindividual character. Besides, this phenomenon is transmitted from the past, and it is permanent, strong, continuous, efficient, and respected by the actors. Durkheim often exemplifies the social facts in general and their distinctive features by traditions, as well as by phenomena of the same order, namely by customs or rituals. The efficiency of any tradition is based on social sanctions and on respect inspired by it for the members of society. As Durkheim stated, "The traditional customs, even when they have nothing religious or moral, as the holidays, civil ceremonies and fashion are protected by a large variety of sanctions against individual attempts at rebellion. The economic organization is imposed on us by an imperative necessity too." (Durkheim, 1975, p. 27). The influence of tradition and respect for it explains in some degree the resistance to innovations. It depends particularly on the sphere of social life. In religion and morality the innovation and reform generally are labeled as heresy and sacrilege. Consequently, the possibility of changes is equal almost to zero, but in economic sphere the possibility is greater. (Durkheim, 1975, p. 29).

In spite of all Durkheim's statements about the decline of traditionalism in contemporary societies, he believed that the new industrial societies will be based on traditions in a great measure too. Only these new "rational" traditions, being in status nascendi, are quite different from the old, "traditional" traditions. These latter, according to him, will be mainly replaced by the former ones. Old traditions, partly inherited from societies with mechanical solidarity and contained in "collective consciousness", will take some, though small, place in new industrial societies. These latter, Durkheim thought, will be based on two kinds of traditions: old, "traditional" ones, inherited from traditional societies, and new, rational ones, developed in contemporary industrial societies. So, to paraphrase the famous saying, his viewpoint 
on this subject might be formulated as follows: "La tradition est morte, vive la tradition!", "Tradition is dead, long live the tradition!".

It is important to note that Durkheim uses the concept of tradition not only when he uses the word "tradition". He attributes, for instance, the same significance to the expression the "collective habits" that he analyses in his lectures published under the title "The Moral Education" (1925). Here he treats this expression as a true synonym of tradition. He claims sometimes, that traditional behaviour in general is almost identical to moral one. He emphasizes the close affinity and nearly identical character between collective habits, on the one hand, and morality, on the other hand. In fact, from his point of view, a moral rule becomes truly moral and truly a rule only when it becomes traditional one, i.e. regular, continuous, habitual, long and so on. In this connection Durkheim spoke not only about the content of moral rules, but about the moral rules as such, and their traditional character as their specific feature. Regulation, according to him, is a fundamental function of morality. It means that moral behaviour is basically a constant, persistent and invariable phenomenon. It does not depend on contingency and vicissitudes of the present day. Durkheim asserted, “...The morality is essentially a constant phenomenon, always identical to itself...A moral act tomorrow must be the same as it was today, whatever were the personal dispositions of the agent who commits it." (Durkheim, 2012, p. 47). And he added, "Although all collective habits are not moral, all moral practices are collective habits. Therefore, everyone who is not susceptible to everything that is habit, risks also to be not susceptible to morality." (Durkheim, 2012, p. 47). It is evident from these quotations, that Durkheim's expression "collective habits" is synonymous to "tradition", in any case, to one of its basic meanings.

\section{Alternation of Traditions and Ideals: On Durkheim's Philosophy of History}

The Durkheimian concept of anomie is closely related to his interpretation of traditions, morality and social solidarity. ${ }^{9}$ According to Durkheim, there are two primary anthropological needs of individuals, first, in social or group belonging and, second, in normative and value regulation. Anomie is the lack of the latter one. It must be emphasized here that in Durkheimian theory the decline of traditionalism and the rise of rationality in European civilization per se didn't imply anomie. This passage from traditional to modern, industrial, "rational" society is viewed by him as a main "normal" trend of social evolution. This process had begun in the XYIII century and continued up to the epoch that Durkheim could consider as contemporary for him. But, according to him, anomie consists above all in the fact that the decline of the old, "traditional" traditions, which itself is "normal" and fruitful, lasted too long, and for a too long time there was no necessary and worthy substitute for them in the sphere

9 For the fundamental analysis of the concept of anomie see Besnard (1987). 
of ideals. Anomie, and social crisis, consist not in transition from traditionalism to rationalism, but in the "abnormal" vacuum and uncertainty in the domain of norms and values, instead of the "normal" fullness and certainty of this domain.

Unlike Marx, for whom contemporary crisis was above all economic and political, Durkheim, as well as Comte, believed it was essentially a religious and moral one. He testifies to this view point, by saying, "Today traditional morality is shaken and no other has been brought forward to replace it." (Durkheim, 1965, p. 68). He concludes, "In short, the former gods are growing old or dying, and others have not been born." (Durkheim, 1995, p. 429).

It is evident from the above, that the interpretation of traditions in Durkheim's work is closely connected to his treatment of social ideals. He attaches great importance to the latter and thinks them to be a necessary condition for the existence of societies. In the formation and maintenance of ideals Durkheim sees one of the two principal social functions of religion, the second function being, according to him, the maintenance of social cohesion and solidarity. He wrote: "A society can neither create nor recreate itself without creating some kind of ideal by the same stroke." (Durkheim, 1995, p. 425).

The ideals are closely related to traditions in many respects. They are both the carriers, representatives and containers of social norms and values. They both include an element of sacredness, because sacred character has their common source, i.e. society. Finally, what is the most curious thing in Durkheimian theory, they can be transformed into each other.

In his famous paper presented at the International Congress in Bologne (1911), Durkheim outlined a kind of a brief philosophy of history based on the interpretation of the role and interrelations of traditions and ideals (Durkheim, 1979a, pp. 77-96). ${ }^{10}$ He asserted that there was alternation of two types of periods replacing one another in social evolution, "creative" or "innovative", on the one hand, and "ordinary", on the other hand (Durkheim, 1965, pp. 91-92). Evidently, in this case he reproduced a well-known distinction between "critical" and "organic" periods in social evolution made by Saint-Simon and Comte.

But Durkheim introduced some new and special elements in the treatment of this distinction. "Creative" periods are those in which the great ideals are created. These ideals are the basis for civilization and the motor for its further development. This is the time of active exchange of ideas, of collective emotional excitement, close relations and frequent encounters between people. He said, "Such was the great crisis of Christendom,

10 The similar ideas he developed later in "Conclusion" to his "Elementary Forms of Religious Life". See also his "Introduction à la morale" (1920). 
the movement of collective enthusiasm which, in the twelfth and thirteenth centuries, bringing together in Paris the scholars of Europe, gave birth to Scholasticism. Such were the Reformation and Renaissance, the revolutionary epoch and the Socialist upheavals of the nineteenth century." (Durkheim, 1965, p. 92). In such periods social life becomes very intensive, egoistic motives and troubles of everyday life everywhere yield to the general aspiration for the ideal. The ideal strives almost entirely to merge with the real, "At such times the ideal tends to become one with the real, and for this reason men have the impression that the time is close when the ideal will in fact be realized and the Kingdom of God established on earth." (Durkheim, 1965, p. 92). But this exaltation and at the same time illusion, cannot last too long, it is too tiring. When this creative period comes to an end, the intensity of social life, of intellectual and emotional contacts becomes weaker, the individuals return to their everyday, ordinary life.

All the ideas, feelings and actions of "the period of fruitful tempest" remain, but this time in the form of memories which merge no more with reality, they exist apart from it. These ideals are overturned in the past. In fact, they are traditionalized or transformed into traditions. They would die away, if they were not revived periodically by means of various holidays, public ceremonies, sermons in churches and schools, dramatic performances, manifestations, and so on. Nevertheless, all these means only partly and weakly revive the effervescence of innovative epochs and their influence is superficial and transitory. With time, in new "creative" period the ideals are revived again, they are actualized and approach reality anew. Then they are removed from it again, and thus the process goes on.

\section{Traditions, Ideals and Soviet Society: A Durkheimian Perspective}

These ideas of the late Durkheim allow us to understand better the alternation of the utopian and traditionalist types of collective mentality in history, the transformation of one type of mentality into another, as well as of some distinctive features of sociocultural time. The latter is compressed, short and rapid in the "innovative" historical periods, on the one hand, slow and long-winded in the "ordinary" ones, on the other hand. From this view point one can also explain some special features of sociocultural time during the political revolutions that Marx named "the locomotives of history", and the enigma of "impatience" observed very often in revolutionary consciousness.

Such phenomena in interpretation and temporal perception of the ideals can be observed, for instance, in the history of the Russian and Soviet societies. The generation of revolutionaries who made the October revolution in Russia in 1917 was in the grip of the utopian vision of reality. They sincerely believed that their children, let alone their grandchildren, would undoubtedly live in an earthly paradise, i.e. under communism. The communist ideal seemed to be so much in the offing. In 1920 Vladimir Lenin resolutely declared that the members of the Russian Komsomol (Young Communist League) of that time would "be able to start building the edifice of communist society 
and bring it to completion." (Lenin, 1976, p. 17). He promised with confidence that "the generation of those who are now fifteen years old ... will be living in a communist society in ten or twenty years' time..." (Lenin, 1976, p. 21). Today these declarations and predictions, or promises, seem strange and naïve, or, on the contrary, may be considered as hypocritical propaganda tricks. But in this case the chief of the young Soviet State most likely sincerely believed in what he said publicly.

The ideas of this kind in ordinary conditions would be soon enough replaced by more realistic ones. However, they persisted and rather were preserved by the Soviet political power during many decades, due to the various extreme measures, including repressions, brainwashing, isolation from the external world, etc. These ideas were presented even almost fifty years after the October revolution in the well-known declaration by Nikita Khrushchev that "the present generation" of the Soviet people would live under communism. Meanwhile, prudent silence was kept regarding what generation precisely was meant, babies that had just been born, old people or the middle-aged.

But during the period of "stagnation", under the rule of Leonid Brezhnev (19641982), the temporal perspective and retrospective were changed. It became evident in the theory of "developed", or "mature" socialism, elaborated by the Soviet propaganda of that time. This theory no longer mentioned communism, but instead claimed that in the Soviet society the "developed", or "mature" socialism was built and it had to be only perfected and improved. In other words, the achievement of the communist ideal, which in 1920 seemed so close to Lenin, was silently postponed to the vague and indefinite future, or even was recognized as non-existent. Even the word "communism" almost disappeared from the official documents and the media. At the same time, in the ideology and propaganda of the Communist Party of the Soviet Union an attitude to educating the people in the spirit of revolutionary, combatant and working traditions of Soviet society prevailed. This attitude was proclaimed in many official resolutions and documents of the Communist Party.

So, in the Soviet Union, quite in accordance with Durkheimian theory, there were traditionalization and ritualization of the communist ideal, its transfer from the "bright future" into the "glorious past". At the beginning of the Soviet period of the Russian history, just after the October revolution of 1917, the tradition was at the service and in obedience of utopia, whereas with time, on the contrary, the utopia found itself submitted to tradition, selected and constructed in a certain way by political power.

\section{Morality of Traditions and Morality of Ideals}

From what is written above, the Durkheim's view on the sources of basic sociocultural innovations becomes partly clear. These sources are the social ideals, "Ideals are not abstractions, cold intellectual concepts lacking efficient power. They are essentially 
dynamic, for behind them are the powerful forces of the collective." (Durkheim, 1965, p. 93). These ideals in their essence are the innovative forces. They are based on reality, emerge from it, but they add something new to the existing reality. From already existing elements ideals make new combinations, produce new results, renew social reality.

Durkheim emphasized social, collective nature of ideals, as well as of innovations which he treated as results of the latter. The driving force of the ideals consists above all in provoking, especially in the "innovative" epochs, of the states of collective enthusiasm and emotional excitement, or "effervescence".

In this respect, the Durkheimian theory partly approaches the Weberian interpretation of charisma as an innovative and revolutionary force exposed to routinization. However, in contrast to Weber, Tarde and many others, he does not regard an individual to be a source and motor of innovations. According to Durkheim, an individual innovator is the same representative of society as an individual traditionalist. While discussing this question with one of his opponents, he said, "A rebellion against the traditional morality you conceive of as a revolt of the individual against the collective, of personal sentiments against the collective sentiments. However, what I am opposing to the collective is the collective itself, but more and better aware of itself." (Durkheim, 1965, p. 66). By the way, in the quoted statement, opposing collectivity which understands itself "more" and "better" to traditional morality, we see again the anti-traditionalist and "modernist" attitude of Durkheim.

Thus, even the individuals who are the agents and initiators of innovations represent, as Durkheim pointed out, a society or a group. Even the criminals, violating the established, traditional social norms may be considered innovators, bringing other norms, social as well, but in status nascendi. So, even a criminal innovator, opposing himself to a society, may follow the norms of this very society, but future norms, the coming ones, not yet established and not understood by society itself. An example of Socrates, mentioned by Durkheim as illustrating this situation is very characteristic in this connection. "According to Athenian law, Socrates was a criminal and his condemnation was entirely just. However, his crime - his independence of thought - was useful not only for humanity but for his country. It served to prepare a way for new morality and a new faith, which the Athenians then needed because the traditions by which they had hitherto lived no longer corresponded to the conditions of their existence." (Durkheim, 1992, p. 102).

It is evident that the most difficult sociological question in this kind of situations is which traditions correspond to the conditions of existence of a society, and which do not. Taking this into account, Durkheim constantly demanded studying these conditions, before judging about the role and significance of some traditional customs and institutions. 
Durkheim made a considerable contribution to the study of the ritual as one of the important forms of traditional behaviour. In "The Elementary Forms of Religious Life" he developed a detailed classification and carried out a careful analysis of rituals in the totemic system of the Australian aborigines (Durkheim, 1995, Book III). He distinguished the negative (forbidding) and positive cults and thoroughly studied the rituals of sacrifice, imitative (mimetic), representative (commemorative) and piacular rituals. He thought the differences between the religious rituals (holidays, ceremonies, etc.) stricto sensu, on the one side, and non-religious, the profane ones, on the other side, to be unimportant. On the contrary, he stressed the essential similarity between them from a sociological viewpoint, thus continuing the tradition of Montesquieu, Rousseau and Comte. To maintain this principle, he asked rhetorically: "What basic difference is there between Christians' celebrating the principal dates of Christ's life, Jews' celebrating the exodus from Egypt or the promulgation of the Decalogue, and a citizens' meeting commemorating the advent of a new moral charter or some other great event of national life?" (Durkheim, 1995, p. 429).

Certainly, Durkheim believed the traditions to be one of the main factors of social solidarity. However, according to him, in some historical periods, in some social situations, they can hinder and destroy solidarity in society. This takes place at times when traditions no longer correspond to changed "social conditions". Meanwhile, innovations, which are partly the future traditions, become necessary for maintaining solidarity and generally for the development and even survival of societies. Thus, Durkheim for whom solidarity was synonymous to sociality, believed sociocultural innovations to be a kind of social imperative, as important for the social well-being as traditions are.

\section{Conclusion}

It follows from the above that Durkheimian theory of traditions, along with his theories of morality, ideals and innovations, is subtle enough and can be usefully applied today, at the time of high modernity or "postmodernity". Durkheim did not simply oppose tradition to innovation, but thought them to be interconnected, interactive and interpenetrating processes that can even be transformed into each other. His ideas are a fruitful contribution to the study of such phenomena as multiple modernities and functions of traditions in modernizations and post-modernizations of contemporary societies. Within the last decades in theoretical field we can observe the process that can be named "modernization of the theories of modernization". It consists, above all, in the understanding of spatial and temporal plurality and diversity of modernizations. In this connection the traditions may be appreciated not only as an opposite of and a hindrance to modernizations and innovations, but as their condition and basis. At the same time, one can witness the process of transformation of traditions as such, a kind of modernization of traditions themselves, their nature, content and formation processes. Today traditions 
very often can exist and survive only because of innovations. Beside the "traditional traditions" based on the habit, there appear new forms of traditions derived from different sources, wherever by the means of fashion, informational and global innovations. So, the old idea of modernization as detraditionalization is now inconsistent with reality. Then, the reflexive traditionalization should be a necessary element, or an addition, of reflexive modernization, which was talked about by those social thinkers, as Jürgen Habermas, Anthony Giddens or Ulrich Beck. Durkheim's theory of tradition may be considered as a fruitful contribution to understanding of this phenomenon.

Grant Support: The author received no financial support for this work.

\section{References}

Besnard, P. (1987). L'Anomie. Ses usages et ses fonctions dans la discipline sociologique depuis Durkheim. Paris : PUF.

Durkheim, E. (1951). Suicide. A study in sociology (J. A. Spaulding \& G. Simpson, Trans.). Glencoe (Ill.): The Free Press.

Durkheim, E. (1965). Sociology and philosophy (D. F. Pocock, Trans.). London: Cohen \&West.

Durkheim, É. (1975). La sociologie et son domaine scientifique (1900). In V. Karady (Prés.), Émile Durkheim. Textes 1. Éléments d'une théorie sociale. Paris: Les Éditions de Minuit.

Durkheim, E. (1979a). Introduction to ethics. In W. S. F. Pickering (Ed.), Durkheim: Essays on morals and education (H. L. Sutcliffe, Trans., pp. 77-96). London, Boston and Henley: Routledge \& Kegan Paul.

Durkheim, E. (1979b). A discussion on the notion of social equality. In W. S. F. Pickering (Ed.), Durkheim: Essays on morals and education. London, Boston and Henley: Routledge \& Kegan Paul.

Durkheim, E. (1992). The rules of sociological method and selected texts on sociology and its method (W. D. Halls, Trans.). Houndmills, Basingstoke and London: The Macmillan Press Ltd.

Durkheim, E. (1995). The elementary forms of religious life (K. E. Fields, Trans.). New York \& London: The Free Press.

Durkheim, E. (1997). The division of labor in society (W. D. Halls, Trans.). New York: The Free Press.

Durkheim, É. (2012). L'éducation morale. Paris: Quadrige / PUF.

Durkheim, É. (2015). Leçons de sociologie. Paris: Quadrige / PUF.

Fish, J. (2005). Defending the Durkheimian tradition. Religion, emotion and morality. Aldershot; Burlington: Ashgate.

Gofman, A. (2014). Chapter 3. Durkheim's theory of social solidarity and social rules. In V. Jeffries (Ed.), The Palgrave handbook of altruism, morality, and social solidarity: Formulating a field of study (pp. 45-70). New York: Palgrave MacMillan.

Gofman, A. (2015). Teorii traditsii v sotsiologuicheskoy traditsii [Theories of Tradition in Sociological Tradition]. In A. Gofman, Tradition, solidarity and sociological theory. Selected Texts. Moscow: Noviy Khronogfaf.

Joas, H. (1996). The creativity of action (J. Gaines \& P. Keast, Trans.). Cambridge: Polity Press; Blackwell Publishers Ltd. 
La Question religieuse. Enquête internationale. (1907). Mercure de France, T.67. N237. $1^{\text {er }}$ Mai.

Lenin. (1976). The tasks of the youth leagues. Speech delivered at the third all-Russia congress of the Russian Young Communist League. Moscow: Progress Publishers.

Parsons, T. (1949). The structure of social action. Glencoe: The Free Press.

Turner, S. (Ed.). (1993). Emile Durkheim: Sociologist and moralist. London: Routledge.

Wallwork, E. (1972). Durkheim, morality and milieu. Cambridge, Mass.: Harvard University Press.

Watts-Miller, W. (1996). Durkheim, morals and modernity. London: UCL Press.

Weber, M. (1991). Science as a vocation. In H. H. Gerth \& C. Wright-Mills (Eds., Trans.). From Max Weber. Essays in sociology. London: Routledge. 
